\title{
Attitudes towards the Efficiency of English Culture Treatment at Schools: A Case of Iranian Kurdish EFL Learners
}

\author{
Sahar Ahamdpour \\ English Language Department, Bonab Branch, Islamic Azad University, Bonab, Iran \\ Davud Kuhi \\ English Language Department, Maragheh Branch, Islamic Azad University, Maragheh, Iran
}

\begin{abstract}
Language is used for communication and it is a carrier of culture. Culture and language are inseparable. If learners are successful in understanding and use of the target language, they need to have good knowledge of cultural aspects of the foreign language as well. Therefore it is essential to teach culture and language simultaneously. The present study aims to understand Iranian Kurdish EFL learners' attitude towards the way culture is addressed and treated in English language course at high schools. To this end, two hundred and fifty female EFL learners were selected based on availability sampling from two high schools in Boukan, West Azerbaijan and were asked to complete the attitude questionnaire. The results indicated that Iranian Kurdish EFL learners hold negative attitudes towards the way culture is treated at English course in Iranian high schools. At the end, the paper provides some recommendations for policy makers, textbook designers, and teachers in order to foster cultural awareness in teaching and learning process.
\end{abstract}

Index Terms - culture, cultural awareness, attitudes, English language teaching in Iran, English as a foreign language, communicative skills

\section{INTRODUCTION}

Teaching foreign languages includes more than building knowledge of grammar, phonology, and lexis. It consists of building cultural competence and understanding the culture of foreign language as well to facilitate communication. Language and culture are inseparable and one cannot think about a language without considering the culture of its native speakers. If we separate these two concepts from each other the significance of them will be extremely decreased. Language reflects culture in such a way that people can be able to observe culture via language (Brown, 1994).

\section{A. Culture and Language}

Culture is a very comprehensive concept. From anthropological point of view, culture is the way people live (Chastain, 1988). Culture provides the context of living, thinking, feeling, and relations with the other members of the society. It manages our behavior and makes us aware and sensitive to different issue. It helps us to know about other people's expectations from us as a member of the society and makes us aware of our responsibility towards others (Cakir, 2006).

There are different attitudes towards the type of culture within teaching English as a foreign language. Byram (2012) as cited by Savu (2016) mention that culture should be taught along with the English language to 'acculturate' learners into native speakers' culture. On the other hand, since English is a lingua franca, Jenkins (2005) states that we can approach this language in a culture-free context. In addition, two other approaches - modernist and postmodernist focus on this very issue. The modernist or knowledge-based perspective considers culture as a static notion besides the language. In this approach knowing the code of language - four language skills along with grammar and vocabulary - is enough and learners are merely passive recipients of knowledge (Saeidi \& Zamanian, 2017). Therefore, this approach separates cultural competence from language competence. On the other hand, in the second approach, culture is seen as a dynamic phenomenon and language and culture are interwoven and they are learn together. These days culture in learning foreign languages has changed from culture as information to community culture that is the same with it in special and historical manners (Koike \& Lacorte, 2014).

Culture is interrelated with language learning, since language reflects values of a society, once you use a nation's language, more or less, you become a part of the nation's customs, attitudes, and behavior. Making communication in a foreign language does not merely about using a language lexically and grammatically correct, but you need to be socially competent in order to avoid misunderstandings, frustration or even social defects. Accordingly, people who are able of communicating through another language while they have no information about its surroundings, social situations, customs or philosophical sides of the targeted language (Farooq, Soomro, \& Umer, 2018). The relationship between culture and language is such a close one that without culture language learners are at risk of becoming "Fluent 
Fools" (Bennett, Bennett, \& Allen, 2003, p.237).Hence, culture plays a key role in language teaching as well that is explained in the next section.

\section{B. Role of Culture in ELT}

Teaching culture has an effective role in teaching linguistic and communication competences. It provides the learners with the opportunity of gaining/changing attitudes towards native English speakers and their language. As a result, the learners may hold a positive motivation towards English. It goes without saying that positive attitudes towards a language enhance the process of learning the language (Gardner, 1985), so making learners familiar with English culture increases English language learning. By teaching culture, learners' intellectual curiosity leads them to notice that they can express their feelings, thoughts, and needs in the ways other than their own culture. However, we cannot find a known method in order to teach the class about cultural conditions. The teachers and lesson plan designers should prepare the cultural content in the books and concentrate on teaching language characteristics in accordance with the part of culture in learning languages (Abushihab, 2016). Accordingly Educational policy makers, teachers, and learning materials such as textbooks play a significant role in English language and culture teaching/learning process.

\section{Textbooks}

Culture as an inseparable component of foreign language learning should be present in English textbooks as well. Abdzadeh (2017) addresses culture in textbooks from two perspectives. First, localizing textbooks which refers to designing the material in a way that increase learners' engagement with language learning experience as well as making meaning out of it (Tomlinson, 2012) ; therefore, the gap between the learner and the teaching content decreases to a great deal. In fact, global English textbooks are criticized for their exclusion of student's local cultures (Matsuda \& Friedrich, 2011). On the other hand, limiting content of English textbook to local culture has some disadvantages. It decreases learners' intercultural competence and makes them unable to use language naturally while communicating. Based on what has been mentioned so far,textbooks should contain the culture of English speaker countries. The cultural content of textbooks should focus on geography, education system, food and drink, festivals (Saeidi\&Zamanian, 2017), and different customs at different occasions in order to provide deeper cultural insights in learners, enhance their cultural awareness, and improve their communicative competence.

\section{Teachers}

A teacher should be aware of both native and target culture and integrate language and culture teaching meticulously. Teachers tend to introduce target culture to the learners through proper inputs, textbooks, and appropriate activities in the classroom. For example, numerous techniques such as role play, readings, films, simulation, games, culture assimilators, culture capsules and culture-grams can be applied in the classroom to assist learners in practicing and internalizing English language and culture (Chastain, 1988).Accordingly, teacher training programs should prepare the teachers to transfer target culture in the classroom. Moreover, it should help teachers in learning how to draw the students' attentions to the distinctiveness of the native and target cultures rather than value judgments. Therefore, when a teacher tries to teach a language, he/she should not be judgmental or non-subjective (Peterson \& Coltrane, 2003). Teachers should not undermine native values or over treasure the target culture. In addition, in order to increase learners' achievements, teachers are to change the classroom practice in the directions of 'thinking globally', 'acting locally' and 'thinking and showing local and universal acts. Universal acts are those that are international. Students should possess a lot of knowledge to have careers in future (Badrkhani, 2017). While some learners show positive attitudes towards English language and culture, there are learners who feel alienation towards English language, culture, and people; therefore, one of the other main tasks of a teacher is to be sensitive to the fragility of learners through using facilitative techniques that promote cultural awareness and understanding (Cakir, 2006).

\section{E. Cultural Awareness and Language Teaching/Learning}

Cultural awareness begins with developing sensitivity and understanding of people's beliefs, attitudes, behaviors and values. It leads people to more critical thinking. They believe that being aware of the cultural conditions, is a slowly developing understanding of how culture is, while you understand better yourself, about your culture and about the cultures of other people, and also a fine understanding of the cultures' differences. From Tomalin and Stempleski (1993) cultural awareness has three main features: awareness of one's own culturally-induces behavior, awareness of the culturally-induced behavior of others, and ability to explain one's own cultural standpoint. Suleiman (1995) states that finding out about the cultural awareness, will make the understanding of different views of the language easier, which makes language learning and teacher more productive.

Cultural awareness in language teaching is triggered by the fact that almost all of the learners are not exposed to cultural elements; therefore, they may face a notable challenge in communicating meaning to native speakers (Farooq, Soomro, \&Umer, 2018). Cultural awareness broadens the minds of the learners, increase tolerance and create cultural empathy and sensitivity towards the native and target culture. Therefore that's why the teachers need to have an analytical view of the learners' knowledge requirements, about the knowledge of cultures, and acting in a fine manner of awareness. (Shemshadsara, 2012). Teachers should read up on the cultural characteristics, history and customs of the learners' native country as well as the target countries. Teachers need to deliver language instruction without bias, 
discrimination or prejudice. Being culturally aware helps teachers to meet the needs of their learners and create an environment in which they feel comfortable and ready to learn. Provided with proper amount of cultural input in the classroom, Students can mix the cores of native and target cultures and build their own feeling and belief about the distinctions of culture between cultures (Savu, 2016). Accordingly in this part students fill the space between cultural distinctions and get to their personal and general targets (Crozet \&Liddicaot, 2000). In this regard Saeidi and Zamanian (2017) mention that:

The main aim of the second language is facilitating the students to work with situations of the target culture while using their own culture which is of utmost importance in the communication between cultures (p. 258).

All in all, Cakir (2006) mentions the following items as the main reasons for arising cultural awareness in EFL learners:

-Making the skills of communication stronger,

-Finding out about the patterns of language and behavior about the target and the native cultures at a more understandable level,

-Making the international and different cultures understanding better,

-Making instruction more enjoyable to expand the awareness of the potential mistakes that may be related to comprehension, interpretation, and translation and communication.

It is good to say that there are some worries about, in what situation another culture can be taught in a classroom about foreign languages. The students are required to have suitable information about their own culture to stop sole focus on the target language. Therefore the teacher has to be able to create an atmosphere in which he can integrate cultural elements into actual language teaching. To be able to do this a teacher must have good information about both languages and cultures, since it may be possible for the students to mix up the elements in both cases (Farooq, Soomro, \&Umer, 2018).

\section{F. The Present Condition of ELT in Iran}

Iran is a nation with various races, religions, lifestyles, languages, and cultures. Although several languages and dialects are spoken in Iran - such as Azeri, Gilaki, Balouchi, Kurdish, Arabic, etc. - Farsi is the official language of this country and used for giving instructions at schools and other academic places. Therefore, most of Iranian students are bilingual or even multilingual. Since language and culture are interlinked, Iranian students are bicultural/multicultural as well. Thus, Iranian foreign language teachers face a significant challenge in terms of dealing with target and native culture(s) of the students. Since the present study aims at exploring Kurdish EFL learners' attitudes towards the way English culture is treated in English classes at school, it is conducted in Boukan, a Kurdish speaking city located in West-Azerbaijan in which Turkish is a dominated language. Besides, Farsi, as the official language of the country, is used at schools. Consequently, EFL learners in Boukan are multilingual and multicultural who are to get familiar with a forth language and culture at EFL classes. This situation might become too challenging for both the teacher and the learners. Teachers must be prepared for elements such as awareness, knowledge and skills of the needed cultures and the learners have to face the challenges of cultural adjustment (Hashim, Johannes, \&Majzub, 2011).

In Iran, English as a foreign language is an obligatory school subject that students are required to learn it since the age of 12 at schools. The most important part of teaching is grammar and reading skills (Riazi, 2005). Classes are relatively crowded for a language class and are teacher-centered. The mentioned factors imply lack of communicative skills namely writing and speaking. (Abdzadeh, 2017). On the other hand, Saeidi and Zamanian (2017) found that for the teachers, intercultural targets are of utmost importance and they prefer to promote acquiring communicative competence via English teaching, but their teaching practice can as yet not be characterized as based on cultural awareness and cultural competence development. They cannot devote extra teaching time to teach culture, because of the tight syllabus they have to follow. They don't pay much attention to the way the culture of a targeted language must be taught, instead they just focus on some limited skills as discussed before. In terms of English education policy in Iran, Abdzadeh (2017) states that English is used as a means to strengthen national identity and promote religious values via language education. She founds that Iranian textbook does not meet learners' needs in terms of cultural awareness. There is a similar situation in Saudi-Arabia as well. Alsamani (2014) reports that English courses of Saudi universities contain little amount of cultural data about native English speakers, because they think that it can have a bad effect on students' behavior and can be a threat to the students' Islamic identity.

English textbooks are all developed, published and distributed under the authority of the Ministry of Education. The text designers do not focus on the techniques and methods of teaching culture of the foreign language in the curriculum, but their focus is on the materials and the topics, which are based on linguistic and grammatical aspects instead (Abushihab, 2016). Therefore the language is only taught at a superficial and at times unnecessary way. The English books in Iranian school give almost no amount of information about the target language country. For instance most of the names of the people or the cities are Iranian. Even if this is a political decision we should admit that it could act as a hindrance towards second language learning (Javdani \& Mahboudi, 2012).Aliakbari (2004) in his investigation of Iranian ELT textbook reports several shortcomings:

1. ELT textbooks in use in Iranian high schools did not prove helpful in developing inter-cultural competence and cultural understanding. It seems that books deliberately or not, distract attention from culture or cultural points. 
2. There were a disproportionate number of topics on science and the related fields. The instructional goals of the text were found deliberately focused and narrow, with a major focus on science. There was almost no reference to other fields such as literature or other arts.

3. Reading passages lacked identity.

4. The texts were limited not only in the depth of cultural information but also in the range of the cultures depicted. Based on what has been mentioned so far, sometimes, to follow the educational policy and cope with the requirements of the book, teachers cannot use a more creative, interpretative or critical approach. This can be considered as restricting the function of ELT.

\section{G. Statement of the Problem}

Several studies have proved that the language is interconnected with culture and culture is important to language acquisition (Byram, 2012). A foreign language cannot be learned properly without being aware of its cultural dimensions. Learning a language in isolation of its cultural roots hinders learners from becoming a socialized into its contextual use. How to communicate successfully is the most important part of language learning process. Accordingly, every element in language learning process, from policy making and text designing to teaching and learning activities, should foster culture learning in foreign language learners. EFL programs and the textbooks offered in Iran do not contain real-life cultural data about English native speakers. Moreover, in order to follow the syllabus, teachers have no time to present the culture of English native speakers; therefore, learners merely get linguistic competence and lack of communicative competence will encounter them with several problems while they want to communicate in English contexts.

\section{H. Significance of the Study}

The results of this study promote the readers' knowledge of Iranian Kurdish EFL learners' attitudes towards the way English culture is addressed in EFL course at school. The findings informs readers to what degree the English language learners would like English culture to be transferred in the classroom , because the learners are the individuals who may communicate with other English native speakers. In addition, the findings of this study bring new insights of Iranian English Learners' tendency toward the cultural issues. This research will help readers how two important factors like language and culture were addressed through textbooks and applied together in English classrooms in Iran. Furthermore, the reader recognizes the relationship between culture and language. In English language classrooms, these two factors are complements of each other.

\section{Research Question}

In order to achieve the objective in this study the following question was addressed by the researcher:

- What are Iranian Kurdish EFL learners' attitudes towards the treatment of English culture in ELT in Iran?

\section{LITERATURE REVIEW}

Cultural awareness is playing a very important role in modern English teaching. It shows and proves to us even more that the culture and the language itself should be taught together and not separately (Byram, 2012). The importance of cultural awareness and its role in teaching/learning process is to the extent that it becomes the researchers' center of attention to have more research equipment to insights towards teachers and learners' attitudes and the role of cultural awareness in fostering foreign language learning. For example, in attempt to provide a valid and reliable research instrument for gaining teachers' attitudes towards critical cultural awareness, Atai, Babaii, and Bazargani (2017) provided a theoretical framework of critical cultural awareness, and developed and piloted a 37-item questionnaire to gather teachers' attitudes towards critical cultural awareness.

The very notion of cultural awareness in EFL teaching and learning process was of interest of many researchers (Shemsdsara, 2011, Cakir, 2006, Savu, 2006).Numerous studies investigated the attitudes, understanding and tendency towards the cultural awareness in both teachers and EFL learners as well as its impact in teaching English. Farooq, Soomro, and Umer (2018) focus on perception and practices of teachers regarding culture and English language teaching in Saudi Arabia. The data were collected from 121 (60 male and 61 female) teachers of different cultural background through a questionnaire on their perceptions and implication of teaching target culture in the classroom through English language courses. It was revealed that all teachers have knowledge about the aspects of the target culture to some extent, but how they deal with the target culture is affected highly by the curricular considerations and limitations.

In another study, Badrkhani (2017) conducted a questionnaire to 120 Iranian teachers (41 males and 79 females) to gain their attitudes and tendency towards the cultural awareness in the teaching context. The results showed that the Iranian male EFL teachers have more opportunities to communicate with people from the other cultures than the female teachers do. EFL male teachers claimed that they have difficulty in finding global subjects that they plan to each. Female EFL teaches said that they have more knowledge about Iranian customs while males claimed that they have more information about the Iranian history. 
A study conducted by Saeidi and Zamanian (2017) investigated perceptions, practices and problems of 100 Iranian EFL teachers regarding raising students' Intercultural Communicative Competence (ICC) awareness. Based on a mixed-method design, using questionnaire, observation, and interview, the findings indicated an apparent disparity between teachers' perceptions about ICC and their current classroom practices. Teachers also identified and discussed a lack of training, time, and support to raise language learners' ICC awareness. This study provides strong empirical evidence supporting the claim that it is difficult for EFL teachers to integrate culture into their teaching in order to develop learners' intercultural competence.

Moreover, a study was conducted on multicultural awareness among preschool teachers in Malaysia by Hashim, Johannes, and Majzub (2011). A stratified random sample of 144 preschool teachers in the state of Selangor was selected. The result of the researches showed us that most of the preschool teachers have an acceptable level of cultural awareness while they teach in all their classes. These results also showed that it is not that much important if the classes are homogeneous or not. So to sum up about this case, it is important to say that we absolutely need more focus and more studies in order to reach ideal levels for having an ideal qualitative approach.

In a similar way, Sakka (2010) aimed at investigating Greek teachers' cross-cultural awareness and their views on cultural diversity in the classroom. People who participated in the study where 100 elementary and secondary teachers. 57 of them females. Cultural awareness was used in order to gather the needed data and the questionnaire was about views on cultural diversity and their roles in different classrooms. The results were shocking and showed very different ideas of the teachers towards this matter which proves to us even more why we need to have further studies in this case. We need a program and training for teachers which are rich in both curricula and the needs of the teachers as well, as these emerge in today's multicultural classroom.

In cultural awareness issue, not only teachers' attitudes and performance are important, but also foreign language learners' tendencies and points of view towards culture and its effect on learning the language play a crucial role in facilitating teaching and learning process. A body of investigation is devoted to this very issue. For instance, Arasteh, Tahriri, and Tous (2016) made a comparison between Iranian EFL students at two different levels (freshman vs. junior) with respect to their attitudes towards foreign culture. One hundred EFL learners were selected based on availability sampling and were divided into two groups according to their level (freshman vs. junior). All the participants were asked to complete the attitude questionnaire. The non-parametric Mann-Whitney U Test was run to test for possible differences between the two independent groups on their attitudes towards foreign culture. The results revealed insignificant difference between the freshmen group and the junior group. Thus, the null hypothesis was confirmed implying that there was not any significant difference between Iranian freshman and junior English major students' attitudes toward foreign culture.

Ahmed (2015) analyzed that a survey was done on 238 undergraduates of English as foreign language students in Malaysia. And in fact there were about 19 items on the questionnaire. The questions were about the elements that these students found about not being able to study and learn well. The barriers if you may call it. There were several objectives towards this tudy.1) the attitudes that these students have about using English in different situations 2) causes that could have influences the effects of learning English for students 3) the perspectives and futures of learning English amongst non-major English students of Malaysia.

In addition, Alsamani (2014) identified the cultural aspects which are proper to be formed into Saudi EFL classrooms, trying to find the sources that these students needed for their knowledge and examining their ideas towards it. The study was about student teachers and language experts. The data that were needed were collected via a test of cultural awareness diagnostic test and the questionnaire that was needed. The results showed us that these students need learning different aspects of the language including the target culture and also that need audio/visual media more than they do right now. The other important result was that their opinions are pretty positive about the target language and people.

\section{METHODOLOGY}

\section{A. Participants}

The research population consisted of high school students of Boukan, West Azerbaijan, and the research sample merely included the students of the third grade. A total of 261 female teenagers within the age range of 16-17 were selected through availability sampling method based on their year of study. However, 11 students were rejected due to incomplete and incorrect responses; therefore, the final participants of the investigation include 250 students. The participants were Kurdish speakers of Boukan learning English as a foreign language at school. It is noteworthy that Farsi is the official language of Iran and used while teaching and giving instructions in all school subjects such as English.

This study is an attempt to investigate the effectiveness of addressing English culture in teaching/learning process in Iranian's Kurdish high schools as well as gaining Kurdish students' attitudes towards this very issue. Accordingly, both qualitative and quantitative methodologies were used to indicate a comprehensive picture of the issue. To do so, two instruments were utilized in order to gather the required data: questionnaire and interview.

\section{B. Instruments}

1. Questionnaire 
In order to gather the quantitative data, an attitude questionnaire was deployed. In a previous study, an adapted version of Tamimi and Shuib's (2009) questionnaire had been utilized by Javdani and Mahboudi (2012). Therefore, a justified format of this research questionnaire was prepared and piloted before applying to the main participants. Following some modifications according to the objectives of the study, a 15-item-questionnaire with a Likert-type scale of 3 points (Agree, Disagree, Don't know) was administered to the participants 3 months after the beginning of the academic year (November 2018). The questionnaire was deployed in English; however, due to different English proficiency levels of the students while administrating the questionnaire, the researcher translated and/or explained some parts in Kurdish/Farsi orally whenever there was a need.

2. Interviews

In order to gain deeper insight towards students' points of view regarding English culture and how well it is transferred through teaching/learning process, a short interview in Farsi/Kurdish was conducted as well to provide the related data for qualitative analysis. The researcher and two English language teachers (M.A. in TEFL) of the same high school conducted the interviews right after the completion of the questionnaire by the participants. Each interview took 3-4 minutes and audio-taped.

The participants were to provide answers to the following questions:

1. Do you like learning English? Why?

2. Would you like to take more courses in English language?

3. Are you familiar with English culture (customs, occasions, social relations, etc.)?

4. How do you like English culture?

5. How much do you learn about English culture in your English course at school?

\section{Data Analysis}

Statistical analysis of the data gives a comprehensive image of students' attitudes towards English language culture and efficacy of the way it is addressed in Iranian high schools. Accordingly, the percentage of provided answers to the 15 questions of the questionnaire was calculated by SPSS 18, and the results are provided in Table 1.

D. Results

TABLE I.

THE RESPONSE PERCENTAGES OF KURDISH STUDENTS’ ATTITUDES TOWARDS ENGLISH CULTURE

\begin{tabular}{|c|c|c|c|}
\hline Item & $\mathbf{A}$ & $\mathbf{D}$ & DK \\
\hline 1. There is little place for culture in textbooks in Iran. & 69.3 & 12.7 & 18.0 \\
\hline 2. The content materials or textbooks are shallow and superficial. & 70.0 & 16.7 & 13.3 \\
\hline 3. The English taught in Iran is a representation of Persian thoughts and ideology. & 70.7 & 23.0 & 6.3 \\
\hline 4. English teaching in Iran does not foster learner's intercultural communication in English. & 85.0 & 9.7 & 5.3 \\
\hline 5. At least some subjects like physics and chemistry should be taught in English at the secondary level in Iran. & 42.7 & 40.0 & 17.3 \\
\hline 6. The teaching of English should start as early as the first grade in the Iranian schools. & 62.3 & 25.7 & 12 \\
\hline 7. English textbooks should focus on target culture. & 60.7 & 24.0 & 15.3 \\
\hline 8. English textbooks should focus on native culture. & 40.7 & 49.3 & 10.0 \\
\hline 9. English textbooks should focus on international target culture. & 59.7 & 17.3 & 23.0 \\
\hline 10. Most selected English input is neutral and artificial. & 71.7 & 11.0 & 17.3 \\
\hline 11. English teachers and students should be permitted to decide what & 43.3 & 23.0 & 33.7 \\
\hline 12. English teaching in Iran is based on censorial rather than pedagogical motives. & 58.3 & 22.0 & 19.7 \\
\hline 13. Almost all English teachers know the significance of natural and authentic texts. & 39.3 & 11.7 & 49.0 \\
\hline $\begin{array}{l}\text { 14. Iranian students could have better opportunities if English were taught as effectively as it is being taught in the } \\
\text { neighboring countries. }\end{array}$ & 45.0 & 12.7 & 42.3 \\
\hline 15. The government should decrease its direct influence on the education in general and English teaching in particular. & 31.7 & 20 & 48.3 \\
\hline
\end{tabular}

Note: N= 250; A = Agree; D= Disagree; DK = Don't Know. Values are all in percentages.

Attitudes of Iranian Kurdish high school students towards how English culture is learnt and transferred were gathered by an attitude questionnaire and the percentages of the answers were calculated and analyzed. As it can be seen from Table 1, about two third of the students $(69.3 \%, 173$ participants) believe that there is little place for culture in textbooks in Iran. Interestingly, 70\% students (175 participants) hold the idea that the content materials or textbooks are shallow and superficial. Along with this result, almost the same number of students express that the English taught in Iran is a representation of Persian thoughts and ideology. A notable majority of the students (85.0\%, 212 participants) believe thatEnglish teaching in Iran does not foster learner's intercultural communication in English, at the same time, 42.7\% (107 participants) of the students incited that at least some subjects like physics and chemistry should be taught in English at the secondary level in Iran. More than half of the students $(62.3 \%, 155$ participants) think that the teaching of English should start as early as the first grade in the Iranian schools.

Additionally, $60.7 \%$ believe that English textbooks should focus on target culture. On the other hand, less than half of the students $(40.7 \%, 102$ participants) preferred textbook's focus on native culture and $59.7 \%$ of the students are interested in international target culture. A great deal of students (71.7\%, 179 participants) hold the idea that Most selected English input is neutral and artificial. 43.3\% (108 participants) of the students' responses indicate that English teachers and students should be permitted to decide what is culturally necessary or unnecessary. It is worth mentioning that more than half of the students $(58.1 \%)$ think that English teaching in Iran is based on censorial rather than 
pedagogical motives. Moreover, only 39.3\% of students (98 participants) believe that almost all English teachers know the significance of natural and authentic texts, and 45.0\% (112 participants) of the responses showed that Iranian students could have better opportunities if English were taught as effectively as it is being taught in the neighboring countries. Last but not least, only $31.7 \%$ (79 participants) of the participants felt that the government should decrease its direct influence on the education in general and English teaching in particular.

\section{DISCUSSION AND CONCLUSION}

The results of the data analysis along with the interviews show that, on the one hand, Iranian Kurdish students possess positive attitudes towards English language, English learning, and English culture. Not only are they eager to learn this language properly, they also would like to take more courses in English and they think the teaching of English should start as early as the first grade in the Iranian schools (62.3\%). On the other hand, a great deal of the participants hold negative attitudes towards the way English culture is addressed in the English course. Students are aware of the fact that English learning in Iran does not foster learners' intercultural communication in English. Accordingly, this issue can be addressed from three aspects:

First, policy makers and textbook designers in some countries such as Iran think that knowledge of another culture especially western culture will disconnect their people - in this case students - from their native culture and leave a negative effect on their attitudes and behavior towards their own culture; therefore, some aspects of western culture are eliminated from Iranian English course syllabus by the authorities (Javdani\&Mahboudi, 2012). Although teaching four language skills has also been emphasized as one of the main aims of the national curriculum, careful analysis of the curriculum document suggests that its main concern is about reading comprehension and grammar, and the target culture has no way in the teaching/learning process. This fact is in line with the study's findings that report more than half of the students believe that English teaching in Iran is based on censorial rather than pedagogical motives, as well as $48.3 \%$ of the students don't know whether government should decrease its direct influence on English teaching or not.

Secondly, teachers have a significant role in arising cultural awareness in the learners. In spite of supporting intercultural objectives and are tendency to promote the acquisition of intercultural communicative competence through their English teaching, Iranian teachers neglect cultural aspects in their teaching process. It is because they cannot afford extra teaching time to teach culture, since they have to stick to the tight syllabus they should follow. Moreover, teachers deal with culture to the extent they appear in the textbooks and no supplementary instrument such as book, videos can be used in teaching.

Last but not least, the efficacy of Iranian English textbook - as a main means to provide English culture - is under question. More than half of the students would like their books to focus on English culture (60.7\%) as well as international target culture (59.7\%) rather than Iranian culture (40.7\%). However, the focus of English textbooks in Iran is merely on the native culture and no English culture input is available in the textbooks. Along with the same line, a significant majority of the students $(71.7 \%)$ believe that most selected English input is neutral and artificial; therefore, the need to have related authentic input and material is completely felt.

With an eye to what has been mentioned so far there is no surprise that $45 \%$ of Iranian students think that they could have better opportunities if English were taught as effectively as it is being taught in the neighboring countries.

The findings of our study revealed that the status of cultural awareness and practice in EFL program is far from satisfactory. The results indicated that Iranian Kurdish EFL learners hold negative attitudes towards the way culture is addresses in English course at school. Although they have tendencies to learn more about English language and culture, the educational policies, curriculum, and accordingly teachers and textbooks don't give them the chance of acquiring paralinguistic features of language besides its linguistics skills. Language learning and cultural awareness are related and they ought to be taken into consideration while designing syllabuses of foreign languages. The curriculum planners ought to provide learners with a sample of the cultural aspects so that they can share knowledge with native speakers. In addition, language teachers must become familiar with the different cultures and gaining their knowledge. While learning English language, students may fail to recognize the importance of the different cultures, but the EFL teachers would help them to consider the importance of this issue. Teachers should remind the students that the people with different cultural backgrounds are also respected and appreciated.

The findings of this study recommend the Iranian material developers to add English cultural items in textbooks. That is, students' textbooks need to be prepared in a way that could make more opportunity for the students to get more familiar with the foreign culture. In fact, learners are in need of textbooks that make them more interested and motivated to enhance their positive attitude towards foreign culture. By doing so, learners are motivated and raise their communicative skills along with linguistic skills, and are able to communicate properly.

To conclude, further studies can be conducted to explore the affecting factors of teachers', learners' attitudes towards the culture. Moreover, the effect of cultural awareness on students' language achievements on EFL learners regarding different cultural background, English language proficiency level, age, gender, etc. can be investigated. 


\section{APPENDIX. QUESTIONNAIRE}

Dear Students,

The present questionnaire's aim is to learn about what you believe in terms of English language teaching and learning process, content of your English textbooks, and your point of view towards the relevancy of natural input to your success in your English course. The researcher thanks you for your kind participation in advance.

What are your attitudes towards the following issues?

\begin{tabular}{|c|c|c|c|}
\hline Items & Agree & Disagree & Don't know \\
\hline 1. There is little place for culture in textbooks in Iran & & & \\
\hline 2. The content materials or textbooks are shallow and superficial. & & & \\
\hline 3. The English taught in Iran is a representation of Persian thoughts and ideology. & & & \\
\hline $\begin{array}{l}\text { 4. English teaching in Iran does not foster learner's intercultural communication in } \\
\text { English. }\end{array}$ & & & \\
\hline $\begin{array}{l}\text { 5. At least some subjects like physics and chemistry should be taught in English at } \\
\text { the secondary level in Iran. }\end{array}$ & & & \\
\hline $\begin{array}{l}\text { 6. The teaching of English should start as early as the first grade in the Iranian } \\
\text { schools }\end{array}$ & & & \\
\hline 7. English textbooks should focus on target culture. & & & \\
\hline 8. English textbooks should focus on native culture. & & & \\
\hline 9. English textbooks should focus on international target culture. & & & \\
\hline 10. Most selected English input is neutral and artificial. & & & \\
\hline $\begin{array}{l}\text { 11. English teachers and students should be permitted to decide what is culturally } \\
\text { necessary or unnecessary. }\end{array}$ & & & \\
\hline 12. English teaching in Iran is based on censorial rather than pedagogical motives. & & & \\
\hline $\begin{array}{l}\text { 13. Almost all English teachers know the significance of natural and authentic } \\
\text { texts. }\end{array}$ & & & \\
\hline $\begin{array}{l}\text { 14. Iranian students could have better opportunities if English were taught as } \\
\text { effectively as it is being taught in the neighboring countries. }\end{array}$ & & & \\
\hline $\begin{array}{l}\text { 15. The government should decrease its direct influence on the education in general } \\
\text { and English teaching in particular. }\end{array}$ & & & \\
\hline
\end{tabular}

\section{REFERENCES}

[1] Abdzadeh, Y. (2017). Raising cultural awareness in Iranian English language classroom: Can a tailored course make a difference? (Doctoral dissertation, University of Southampton, 2017).

[2] Abushihab, I. (2016). The effect of cultural awareness on motivating students to learn English as a foreign language in Jordan.Journal of Foreign Languages, Cultures and Civilizations, 4(1), 51-57.

[3] Ahmed, S. (2015). Attitudes towards English language learning among EFL learners at UMSKAL. Journal of Education and Practice, 6 (18), 6-17.

[4] Aliakbari, M. (2004).The place of culture in the Iranian ELT textbooks in high school level. Paper presented at the $9^{\text {th }}$ PanPacific Association of Applied Linguistics Conference, Namseoul University, Korea.

[5] Alsamani, A. (2014). Foreign culture awareness needs of Saudi English language majors at Buraydah community college. English Language Teaching, 7(6), 143-153.

[6] Arasteh, F., Tahriri, A., \& Tous, M. (2016). The relationship between attitudes towards foreign culture and language proficiency level: A case of Iranian EFL learners. Journal of Applied Linguistics and Language Research, 3(1), 241-245.

[7] Atai, M., Babaii, E., \& Bazargani, D. (2017). Developing a questionnaire for assessing Iranian EFL teachers' critical cultural awareness (CCA). Journal of Teaching Language Skills (JTLS), 36(2), 1-38.

[8] Badrkhani, P. (2017). Iranian male and female EFL teachers' attitudes toward intercultural education: teaching L2 and transfer of culture. Journal of Applied Linguistics and Language Research, 4(6), 136-152.

[9] Bennett, J., Bennet, M. \& Allen, W. (2003). Developing intercultural competence in the language classroom. Greenwich, CT: Information Age.

[10] Brown, H.D. (1994). Principles of language learning and teaching. The USA: Prentice Hall Regents.

[11] Byram, M. (2012).Language awareness and (critical) cultural awareness-Relationships, comparisons and contrasts. Language Awareness, 2l(1-2), 5-13

[12] Cakir, I. (2006). Developing cultural awareness in foreign language teaching. Turkish Online Journal of Distance Education TOJDE, 7(3), $154-161$.

[13] Chastain, K. (1988). Developing second-language skills. The USA: HBJ publishers.

[14] Crozet, C., \&Liddicoat, A.J. (2000). Teaching culture as an integrated part of language: implications for the aims, approaches and pedagogies of language teaching. In A.J. Liddicoat\& C. Crozet (Eds.), Teaching languages, teaching cultures (pp. 1-18). Melbourne: Applied Linguistics Association of Australia.

[15] Farooq, M., Soomro, F., Umer, M. (2018). English language teaching and cultural implications in Saudi Arabia. International Journal of English Linguistics, 8(3), 177-185.

[16] Gardner, R. C. (1985). Social psychology and second language learning: The role of attitudes and motivation. London: Edward Arnold.

[17] Hashim, S., Johannes, H., Majzub, R. (2011). Cultural awareness among preschool teachers in Selangor, Malaysia. Procedia Social and Behavioral Sciences, 15, 1573-1579. 
[18] Javdani, F., \&Mahboudi, H.R. (2012). The teaching of English in Iran: The place of culture. Journal of Language and Culture, $3(5), 87-95$.

[19] Jenkins, J. (2008). ELF at the gate the position of English as a Lingua Franca. Modern English Teacher, 17(2), 15.

[20] Matsuda, A., \& Friedrich, P. (2011). English as an international language: A curriculum blueprint: World English, 30(3): 332344.

[21] Peterson, Elizabeth, and Bronwyn Coltrane. (2003). "Culture in second language teaching. ERIC Digest." Retrieved from ERIC database, ED99CO0008.

[22] Saeidi, M., \& Zamanian, J. (2017). Iranian EFL teachers' perceptions, practices, and problems regarding raising students' intercultural awareness. International Journal of English Linguistics, 7(4), 257-266.

[23] Sakka, D. (2010). Greek Teachers' cross-cultural awareness and their views on the classroom cultural diversity. Hellenic Journal of Psychology, 7(9), 98-123.

[24] Savu, E. (2016). Intercultural awareness in teaching English as a foreign language. English Language Teaching, 3(5), 55-59.

[25] Shemshadsara, Z. (2012). Developing cultural awareness in foreign language teaching. English Language Teaching, 5(3), 9599.

[26] Suleiman, M. (1995). "Figures of Speech, Symbolism and Communicative Process in the Multilingual Classroom". Paper Presented at the Annual Meeting of Speech Communication Association of Puerto Rico, December (Eric Document, Ed.393960).

[27] Tomalin, B., \&Stempleski, S. (1993). Cultural awareness. Oxford: Oxford University Press.

[28] Tomlinson, B. (2012). Materials development for language learning and teaching. Language Teaching, 45(2), 143-179.

[29] Tomlinson, B., \& Musuhara, H. (2004).Developing cultural awareness. MET, 13(1), $1-7$.

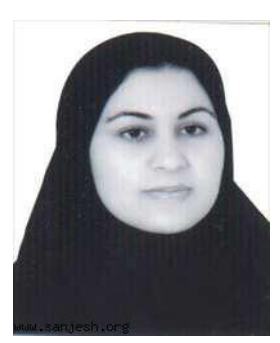

Sahar Ahmadpour is from Boukan, Iran. She is currently PhD student in TEFL in Islamic Azad University (Bonab Branch). She is mainly interested in second language acquisition, psycholinguistics and discourse analysis and cultural studies. She has some publications in national and international journals.

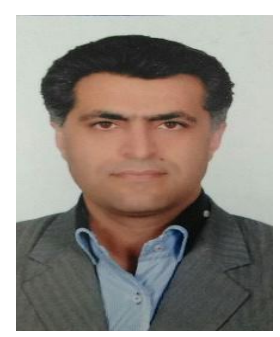

Davud Kuhi, PhD in applied linguistics, is a member of English language department in Islamic Azad University. He has researched extensively on the sociocultural dimensions of scientific and academic discourses. 